\title{
The Analysis of Deixis in the Novel The Fault In Our Stars by John Green
}

\author{
Artika Putri $^{*}$, Made Budiarsa ${ }^{2}$ \\ ${ }^{[12]}$ English Department, Faculty of Arts, Udayana University \\ 1'[artikaputriii@gmail.com], [2[made_budiarsa@yahoo.com] \\ *Corresponding Author
}

\begin{abstract}
This research entitled The Analysis of Deixis in The Novel The Fault in Our Stars by John Green. Deixis is a study to describe the relation between language and contexts in language structure itself. The objectives of this study are (1) to find out and identify types of deixis in the novel The Fault in Our Stars (2) to analyze the function of each deixis type found in the novel The Fault in Our Stars. The data were collected using documentation and observation methods using the reading and note taking techniwques. Qualitative method was used to analyze the data and the method were done by descriptive technique. The method of presenting the result of data analysis was the descriptive method and was done by argumentative technique. The result of the research shows that there are three types of deixis found in the novel The Fault in Our Stars by John Green, namely person deixis, spatial deixis and temporal deixis. Person deixis consists of first person, second person and third person. The first person deixis is used to identify the speaker. The second person deixis is used to show the addressee. The third person deixis is used to show the referent not identified as the speaker or the addressee. The spatial deixis is used to describe a location participant in speech event. Temporal deixis is used to point a certain period of time.
\end{abstract}

Keywords: Deixis, function, novel

\begin{abstract}
Abstrak
Penenelitian ini berjudul The Analysis of Deixis in The Novel The Fault in Our Stars by John Green. Deiksis adalah sebuah studi untuk menggambarkan hubungan antara bahasa dan konteks dalam struktur bahasa itu sendiri. Tujuan dari penelitian ini adalah (1) untuk mengetahui dan mengidentifikasi jenis deiksis dalam novel The Fault In Our Stars (2) untuk menganalisis fungsi masing-masing jenis deiksis yang terdapat pada novel The Fault In Our Stars. Data dikumpulkan dengan menggunakan metode dokumentasi dan observasi yang dilakukan dengan teknik membaca dan mencatat. Metode kualitatif digunakan untuk menganalisis data-data dan metode tersebut dilakukan dengan menggunakan teknik deskriptif. Metode untuk mempresentasikan analisis adalah deskriptif dan dilakukan dengan menggunakan teknik argumentatif. Hasil penelitian menunjukkan bahwa ada tiga jenis deiksis yang ditemukan pada novel The Fault in Our Stars oleh John Green, yaitu deiksis orang, deiksis tempat dan deiksis waku. Deiksis orang terdiri dari orang pertama, orang kedua dan orang ketiga. Deiksis orang pertama digunakan untuk mengidentifikasi pembicara. Deiksis orang kedua digunakan untuk menunjukkan lawan bicara. Deiksis orang ketiga digunakan untuk menunjukan pihak yang tidak teridentifikasi sebagai pembicara atau lawan bicara. Deiksis tempat digunakan untuk menggambarkan lokasi partisipan di sebuah percakapan. Deiksis waktu digunakan untuk menunjukkan periode waktu tertentu.
\end{abstract}

Kata kunci: deiksis, fungsi, novel 


\section{Background of the Study}

How the language is used in context in the study of language or linguistics is considered to be in pragmatics field. It is concerned with the interpretation of linguistic meaning in context. Levinson (1983:9) states that pragmatics is the study of those relations between language and context that are grammaticalized, or encoded in the structure of a language. Pragmatics, in other words, can also be defined as the study of the relationship between the linguistic form (structure) and the user of that form (Yule, 1996: 4). The study of pragmatics covers several sub-fields or domains, and one of them is deixis.

Deixis is a study to describe the relation between language and contexts in language structure itself. It is always found in our daily communication or in text. The term 'deixis' is a technical term derived from the Greek word which has a meaning "pointing" via language (Yule, 1996:9). In order to investigate the message of the speaker, there are such markers which take some elements of its meaning from the situation of the utterance in which it is used. According to Yule (1996:9), those markers are called deictic expressions and are also sometimes called indexicals. Deixis is clearly a form of referring to the speaker's context, with the most basic distinction between deictic expression being 'near speaker' and 'away from speaker'. It is divided into several types; they are person deixis, spatial deixis and temporal deixis. Deixis always needs context to determine the referral. For instance, when a deixis anchors to a previously metioned entity, the phenomenon is called Anaphora; when it points to entity that exists physically within the speech environment, it is called a Deictic, and when it is used to refer to a forthcoming entity, the phenomenon is called Cataphora.
Not only in everyday life, deixis is also found in literature, for example, in novels. It is very interesting to investigate the types of deixis applied in the novel entitled "The Fault in Our Stars" by John Green. Since it is a novel which has many utterances inside it, it also contains many types of deixis that have essential value in the analysis of the novel using the Deixis theory.

\section{Problems of the Study}

a) What types of deixis found in the novel The Fault in Our Stars?

b) How does each deixis type function in the novel The Fault in Our Stars?

\section{Aims of the Study}

a) To find out and identify types of deixis in the novel The Fault in Our Stars.

b) To analyze the function of each deixis type found in the novel The Fault in Our Stars.

\section{Research Method}

There are four aspects of research methods applied; they are data source, method and technique of collecting data, method and technique of analyzing data, and method and technique of presenting analysis.

\subsection{Data source}

In this study, the data were taken from the novel The Fault in Our Stars by John Green. It is the sixth novel by John Green and it was published in 2012 by Duton Books. This novel consists of 324 pages with 25 chapters and this novel also achieved many awards as a bestselling novel. From 25 chapters, 10 chapters were analyzed since all of the data found among 10 chapters already represent the rest. 
This novel has a certain philosophical bent in which it discusses the meaning of life and death. The deixis found in this novel is analyzed and this novel was used because it was written beautifully by John Green in enthralling way using first person narrative and it also contains many types of deixis. The writer was also interested in using this novel because this novel has not been used by any researchers in analyzing deixis.

\subsection{Method and technique of collecting data}

The documentation and observation methods were used in collecting the data using te technique reading and notetaking in order to identify deixis types in the novel The Fault In Our Stars. The novel was read carefully in order to find utterances that contain deixis in the novel. While reading the novel, the sentences or utterances that contain deixis in it were marked. Then sentences or utterances that marked previously were selected by doing note-taking technique. While doing note-taking, it is also important to check the sentence in the novel. Then the last step was classifying the types of deixis used in the novel based on deixis theory proposed by George Yule.

\subsection{Method and Technique of Analyzing Data.}

Qualitative method was used to analyze the data which is not counting the numbers. The method was done by descriptive technique. In order to analyze the data, the sentences and utterances were investigated based on Theory of Deixis proposed by George Yule (1996).

The technique used in analyzing the data included several steps. First, the collected data were classified into their types based on deictic expressions found in each sentence or utterance in the novel The Fault In Our Stars using Deixis theory by George Yule (1996). The focus of the analysis is only on several sentences that have representative values based on the proposed deixis types. The next step was identifying the function of each deixis type already classified; then they were presented descriptively.

\subsection{Method and Technique of Presenting Data}

This study used narrative method and argumentative technique in presenting the data. Narrative method means the data were presented narratively based on the theory by describing and explaining them in sentences. The description of each maxim applied and flouted was presented in the form of paragraph. Meanwhile argumentative technique means that the data were analyzed argumentatively based on the theory by giving opinion or argument about what maxim were applied or flouted by the characters.

\section{Result and discussion}

\subsection{Person Deixis}

\subsubsection{First Person Deixis}

\section{Chap 2/P.22/Par.2/Data 002}

\section{"I failed the driving test three times."}

$I$ in the sentence above refers to the person that spoke at that event which is Augustus. He drives terribly when he takes Hazel to his house. According to Yule, $\boldsymbol{I}$ is identified as a deictic expression that belongs to first person deixis. The deictic expression $\boldsymbol{I}$ belongs to person deixis because it is involved directly in the utterance. This is the deictic expression, in which the information signals who the speaker is.

The word $\boldsymbol{I}$ in the utterance is categorized as anaphoric deictic because the information about the entity is 
already mentioned earlier. $\boldsymbol{I}$ can be directly identified by looking at the previous discourse below; it refers to the speaker of the utterance which is Augustus. The information about this deictic expression was mentioned in the previous lines (line 1 to 5):

"Augustus Waters drove horrifically. Whether stopping or starting, everything happened with a tremendous jolt. I flew against the seat belt of his Toyota SUV each time he braked, and my neck snapped backwards each time he hit the gas."

In the discourse above, Augustus was trying to be a gentleman so he offered Hazel to take her home. But unfortunately, he is a terrible driver as explained by Hazel in the discourse.

\section{Function:}

The deictic marker $\boldsymbol{I}$ in the sentence above refers to the person that spoke at that event which is Augustus. I in the utterance shows as singular pronoun and it refers to the speaker himself. Therefore, the function of the word $\boldsymbol{I}$ in the sentence above is as a subject as it performs the action of the main verb "failed".

\subsubsection{Second Person Deixis}

\section{Chap 1/P.16/Par.7/Data 013}

"I mean, it's gotta be dangerous, storing children with cancer in your heart."

The utterance is said by Hazel. There is possessive determiner your in the utterance. It is the possessive form of the second pronoun you. This indicates that the word your is a deictic expression. According to Yule, this deictic expression belongs to second person deixis.
The information about the word your is mentioned anaphorically in the previous text listed below.

"We are literally in the heart of Jesus," he said. "I tought we were in a church basement, but we are literally in the heart of Jesus."

"Someone should tell Jesus," I said. "I mean it's gotta be dangerous, storing children with cancer in your heart." (Page 16-line 8)

From the text above, we can see that the word your refers to Augustus as the addressee. Hazel was in a church basement with Augustus and the other member of the cancer support group and Augustus thinks that they were in Jesus's heart.

\section{Function:}

The utterance is said by Augustus. He was in a church basement with Hazel and the other member of the cancer support group and he thinks that they were in Jesus's heart. There was second person deixis Your found in the utterance which functions as a possessive adjective and it does not refer to one person, it could be anyone in general.

\subsubsection{Third Person Deixis}

\section{Chap 4/P.62/Par.3/Data 014}

"He never said what happens to the other characters?"

The utterance is said by Augustus and he was talking to Hazel in his house. There is third person pronoun $\boldsymbol{h e}$ in the utterance. This pronoun indicates that it is a deictic expression. According to Yule, this deictic expression can be categorized as third person deixis because it refers to grammatical person in the utterance.

The word he refers to someone not identified as the speaker or the addressee and it is mentioned anaphorically in the 
previous text as listed below. Brief information about the deictic expression in the utterance will be explained by the following text in page 50 - line 9 to 11 .

"I'd written, care of his publisher, a dozen letters to Peter Van Houten, each asking for some answers about what happens after the end of the story. But he'd never responded to any of my letters."

Based on the text, Hazel and Augustus were discussing about a novel that Hazel lent him. It was Hazel's favorite novel written by Peter Van Houten. It can be seen in the text that the word he refers to Peter Van Houten, Hazel's favorite author.

\section{Function:}

There was third person deixis found in the utterance, that is, $\boldsymbol{H e}$. The word he does not refer to the speaker nor the addressee; it refers to the novel's author which is Peter Van Houten. He is a personal pronoun functioning as a Subject as it comes before the main verb "said".

\subsection{Spatial Deixis}

\section{Chap 5/P.79/Par.2/Data 021}

"Hazel, I love you, and you know I'd do anything for you, but we don't-we don't have the money for international travel, and the expense of getting equipment over there - love, it's just not-“"

The utterance is said by Hazel's mom. There is a locative adverb there in the utterance that refers to a certain place. This indicates that the word there is a deictic expression that locates something far from the speaker. This deictic expression, based on Yule's theory, is identified as a spatial deixis as it pointed directly by the speaker and it has spatial relation between the entities to be located. Brief information about the deictic expression there is mentioned anaphorically because it refers back to the word Amsterdam in the previous text as can be seen below:

Still nervous, Mom knelt down to check on Philip to ensure he was condensing oxygen appropriately. I imagined sitting at a sun-drenched café with Peter Van Houten as he leaned across the table on his elbows, speaking in a soft voice so no one else would hear the truth of what happened to the characters I'd spent years thinking about. He'd said he couldn't tell me except in person, and then invited me to Amsterdam. (Page 78 Line 23 to 24 and Page 79 Line 1 to 6)

As already mentioned, based on the text, the word there refers to Amsterdam. There is identified as a spatial deixis in the form of locative adverb, and it is used to demonstrate such place that is relatively distant or far from the speaker.

\section{Function:}

The utterance is said by Hazel's mom. The word there in the utterance is identified as a spatial deixis which refers to a certain place. Based on the text given above, the word there refers to Amsterdam. There is identified as a spatial deixis in the form of locative adverb, and it is used to demonstrate such place that is relatively distant or far from the speaker.

\subsection{Temporal Deixis}

\section{Chap 9/P.23/Par.8/Data 023}

\section{"I'm a lot better now".}

The utterance is said by Hazel, she was talking to Isaac at the weekly Cancer Support Group meeting (which no longer a weekly gathering since she met Augustus). There is a time adverbial now in the utterance. This indicates that it is a 
deictic expression which is based on Yule's theory, categorized as temporal deixis because it indicates the time coinciding with the speaker's utterance.

The speaker is trying to oppose her present situation, which is somehow different from earlier situation. The word now here refers to that time when Hazel attends the Cancer Support Group after her long absence. It can be informed in the text below:

"Okay. Glad to be home, I guess. Gus told me you were in the ICU?"

"Yeah," I said.

"Sucks," he said.

"I'm a lot better now," I said. "I'm going to Amsterdam tomorrow with Gus." (Page 129 Line 1 to 7)

In the text above Hazel is talking to Isaac, the other member of the support group. We can see the word now in the text refers to the time after Hazel was on the ICU. She is a lot better when she talks to Isaac.

\section{Function:}

The utterance is said by Hazel. Deictic marker Now found in the utterance and it belongs to temporal deixis category. The function of the word Now is as an adverb that indicates present activity. The speaker is trying to oppose her present situation, which is somehow different from earlier situation.

\section{Conclusion}

From the analysis of the data it can be concluded that in the novel The Fault in Our Stars by John Green, out of ten chapters, it can be found deixis elements were divided into three categories. The types of deixis that can be found are Person Deixis, Spatial Deixis and Temporal Deixis. Person Deixis also divided into three types, namely First Person Deixis, Second Person Deixis, and Third Person Deixis. There are 385 data types of personal deixis including that 187 data type of first personal deixis, 90 data type of second personal deixis and 108 data type of third personal deixis. There are 30 data type of spatial deixis and there are 9 data type of temporal deixis.

The functions of three kinds deixis types found in the novel The Fault in Our Stars are :

\section{a. Person Deixis}

Person deixis is divided into three categories: First Person Deixis, Second Person Deixis and Third Person Deixis. The function of first person deixis is used to change function of a person who is speaking about himself. The function of second person deixis is used to change function of another person who he or she is told with him. The function of third person deixis is to change the function of another person. The grammatical functions of person deixis are similar to the functions of English pronoun, such as the subject of a sentence or utterance, the object of a sentence or utterance, the possessive adjective, possessive pronoun and reflexive or intensive pronoun

\section{b. Spatial Deixis}

The function of Spatial Deixis is giving shape to the place, seen from the location of the actors in the speaking event, which includes: (a) which is close to the speaker marked by the locative adverb here, (b) away from the speaker but close to the listener marked by the locative adverv there, (c) which is far from the speaker and the listener.

\section{c. Temporal Deixis}

Temporal deixis is used to describe about time whether it's today, tomorrow, yesterday or the day after tomorrow which functioned as an adverb of time. Temporal deixis using temporal form 
indicates time coinciding with the speaker's utterance and the time of the speaker's voice being heard (the hearers 'now').

\section{References}

Grundy, P. (2000). Doing

Pragmatics. Cambridge

University Press, New York.

Horn, L. R. and Gregory W. (2006).

The Handbook of Pragmatic.

Blackwell

Levinson, Stephen C. (1983).

Pragmatics. Cambridge

University Press, London.

Yule, G. (1996). Pragmatics. Oxford

University Press, Oxford. 